
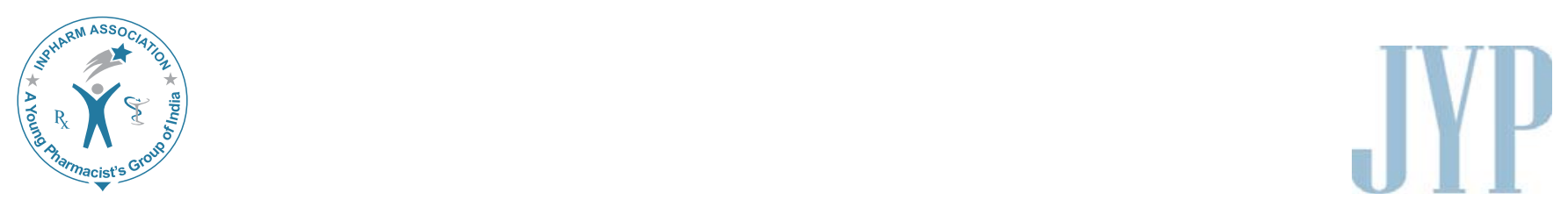

\title{
Antimicrobial Activity of the Extract of Stem Bark of Diplotropis Ferruginea Benth
}

\author{
Cerqueira GS, Rocha NFM, Almeida JRGS'1, de Freitas APF, Lima EO², \\ Filho $\mathrm{JMB}^{2}$, de Freitas $\mathrm{RM}^{3}$, Melo Diniz $\mathrm{MFF}^{2}$ \\ Department of Physiology and Pharmacology, Rua Cel. Nunes de Melo, Fortaleza, \\ ${ }^{1}$ Department of Medicine, Federal University of Vale do São Francisco, ${ }^{2}$ Department of Pharmaceutical \\ Sciences, Federal University of Paraíba, João Pessoa, ${ }^{3}$ Department of Pharmaceutical Sciences, \\ Federal University of Piaui, Teresina, Brazil
}

Address for correspondence: Dr. Gilberto Santos Cerqueira; E-mail: giufarmacia@hotmail.com

\begin{abstract}
This is the first report about the antibacterial activity of Diplotropis ferruginea Benth. In this study, the ethanol extract of $D$. ferruginea was tested for its antimicrobial activity against strains gram-positive and gram-negative. In order to determine the minimal inhibitory concentration, assays were carried out by micro dilution method. The extract was screened for antimicrobial activity, and it showed antibacterial activity against Escherichia coli and Pseudomonas aeruginosa.
\end{abstract}

Key words: Antimicrobial activity, Diplotropis ferruginea, Escherichia coli, Fabaceae, Pseudomonas aeruginosa

\section{INTRODUCTION}

Medicinal plant is any vegetal that containing substances, that can be used therapeutically. These plants are widely used by the alternative medicine. ${ }^{[1]}$ Medicinal plant is any vegetal that containing substances, that can be used therapeutically. These plants are widely used by the alternative medicine. The factor that favors the area of natural products in Brazil is the ethnobotanic and ethnopharmacological knowledge of the Brazilian population. . $^{[2,3]}$

\begin{tabular}{|l|l|}
\hline \multicolumn{2}{|c|}{ Access this article online } \\
\hline Quick Response Code: & \\
\hline & Website: \\
\hline & www.jyoungpharm.in \\
\cline { 2 - 3 } & \\
\hline
\end{tabular}

The Fabaceae have a cosmopolitan distribution, consisting of 700 genera and more than 17000 species. The genus, Diplotropis consists of approximately 22 species, including, Diplotropis ferruginea Benth. ${ }^{[4]}$ Diplotropis ferruginea Benth. (Fabaceae) is a tree popularly known in Northeastern Brazil as "sucupira-preta" and "Sicupira." It is used in folk medicine for the treatment of rheumatism, arthritis, gastric ulcer and diabetes. ${ }^{[5,6]}$

Previous pharmacological study, diplotropin a flavonoid isolated from the bark of the cause of Diplotropis ferruginea inhibited the phasic contractions induced by both acetylcholine and histamine in guinea-pig ileum in a concentration-dependent manner. ${ }^{[7]}$ The purpose of this study was to evaluate the in vitro antibacterial activity of extracts of Diplotropisferruginea stem bark using microdiluition method the susceptibilities of bacteria strains. 


\section{MATERIALS AND METHODS}

Plant material

The stem bark of Diplotropis ferruginea was collected in the municipality of Caraúbas, State of Rio Grande do Norte, Northeastern Brazil in May 2002 to September 2005. Botanic material was identified by Prof. Maria de Fátima Agra, of the Laboratório de Tecnologia Farmacêutica. A voucher specimen (AGRA and D. ALMEIDA 5559) is deposited at the Herbario Professor Lauro Pires Xavier (JPB) of Federal University of Paraiba.

\section{Extraction and isolation}

The dried powdered stem bark of $D$. ferruginea (3 kg) was exhaustively extracted with $95 \% \mathrm{EtOH}$ at room temperature. The extract was concentrated under vacuum yielding $95 \mathrm{~g}$ of the crude product. This was suspended in a $\mathrm{MeOH}: \mathrm{H}_{2} \mathrm{O}(3: 7, \mathrm{v} / \mathrm{v})$ mixture and partitioned with hexane, $\mathrm{CHCl}_{3}$ and EtOAc. The hexane fraction was then subjected to silica gel column chromatography and eluted with hexane, $\mathrm{CHCl}_{3}$ and $\mathrm{MeOH}$ in an increasing polarity gradient to give 152 fractions. The fractions were monitored by TLC and classified into 25 groups. Fraction 97-102 was purified by preparative TLC over silica gel using $\mathrm{CHCl}_{3}: \mathrm{MeOH}(9: 1)$ to afford flavonoid 1 (61 mg). The dry extract was prepared using nebulized spray dry technique. ${ }^{[6]}$

\section{Antibacterial activity}

The antibacterial action of Diplotropis ferruginea was evaluated using the bacteria: Staphylococcus aureus (ATCC 25923), Staphylococcus epidermidis (ATCC 12228), Pseudomonas aeruginosa (ATCC 27853), Escherichia coli (S1) and the following fungi: Candida albicans (LM24), Candida albicans (LM514), Candida albicans (LM905), Candida tropicales (LM 057), Candida krusei (LM 905), Geotrichum sp (LM 515), Tricophyton rubrum (LM 50), Tricophyton rubrum (LM 02), Tricophyton mentagrophytes (LM 740), Penicillium (FCF 281), Fusarium (LM 003), Aspergillus flavus (LM 136) and Fusarium SP (LM 003). The bacteria were grown in Agar Mueller
Hinton (DIFCO Lab. Co). The antimicrobial agent used for control was dimetilsulfóxido (DMSO).

The antibacterial action of extract and flavonoids isolated from Diplotropis ferruginea was performed by Broth Microdiluition method as described in National Committee for Clinical Laboratory Standards with $100 \mathrm{ml}$ aliquots of diluted $\mathrm{EMeOH}$ and standards antimicrobial agents as controls (Peniciline G Benzantine). Bacterial suspensions were standardized with $0.5 \mathrm{ml} \mathrm{Mc}$ Farland standard. ${ }^{[8,9]}$ The minimum bactericidal concentrations were determined by the emergence of a blue color (resazurin) at the wells indicating absence of growth. ${ }^{[10]}$

\section{RESULTS AND DISCUSSION}

The research of the medicinal plants with antimicrobial activity is increasing, with the objective of finding a drug or phytoconstituent with antimicrobial properties and less collateral effects. ${ }^{[1]]}$ The antibacterial activity of extract and flavonoid isolated from $D$. ferruginea presented excellent results against the pathogenic microorganisms tested [Table 1].

The extracts presented antibacterial activity against clinically relevant pathogens (gram positive and gram negative). D. ferruginea stem bark extract was active against Pseudomonas aeruginosa (MIC 1000 and $500 \mu \mathrm{g} / \mathrm{ml}$ for both strains), Escherichia coli (MIC $128 \mu \mathrm{g} / \mathrm{ml}$ for both strains).

The microorganisms have acquired multi resistance to antibiotics and the clinical treatment is been conducted by this fact. As the time passes the therapeutic properties of determined plants are been more investigated in order to fight infections. ${ }^{[12]}$ Then, considering the antimicrobial property different plants were studied and used to treat diverse types of infections. ${ }^{[13]}$ Such data embase the importance of investments in natural products research with the objective to discover new drugs and to defeat the microorganisms defenses mechanisms. ${ }^{[14,15]}$

This study led to the conclusion that the antimicrobial activity of the nebulized extract dry of D. ferruginea was

Table 1: Antibacterial activity of extract of Diplotropis ferruginea Benth

\begin{tabular}{|c|c|c|c|c|c|c|c|c|}
\hline \multirow[t]{3}{*}{ Yeast } & \multicolumn{6}{|c|}{ Extract of Diplotropis ferruginea $(\mu \mathrm{g} / \mathrm{ml})$} & \multirow{3}{*}{$\begin{array}{c}\text { Peniciline } G \\
\text { benzantine } \\
50 \mu \mathrm{g} / \mathrm{ml}\end{array}$} & \multirow{3}{*}{$\begin{array}{l}\text { Control } \\
\text { negative }\end{array}$} \\
\hline & EHA & EHex & $\mathrm{ECHCl}_{3}$ & ED & ED 5 & DPTN & & \\
\hline & 15 & 15 & $15^{3}$ & 1000 & 00 & 15 & & \\
\hline Pseudomonas auriginosas B6 & + & + & + & 12 & 10 & + & 12 & + \\
\hline Escherichia coli $\mathrm{S}-1$ & + & + & + & 14 & 10 & + & 10 & + \\
\hline Staphylococcus epidermides ATCC 12228 & + & + & + & + & + & + & 14 & + \\
\hline Staphylococcus aureus ATCC 6538 & + & + & + & + & + & + & 17 & + \\
\hline
\end{tabular}

+ Growth of bacteria; EHA hidroalcoolic extract; EHex; hexane extract; ECHCl $_{3}$ : chloroformic extract; ED extract Dry; DPTN 370 Flavonoid 
satisfactory against the bacteria Pseudomonas aeruginosa and Escherichia coli. These results are important as a preparation for further research with this same material. However, more specific studies must be carried out to elucidate the mechanisms involved in these activities.

\section{ACKNOWLEDGMENTS}

The authors are thankful to the CNPq and CAPES for financial support.

\section{REFERENCES}

1. Barreto FS, Sousa EO, Campos AR, Costa J, Rodrigues F. Antibacterial activity of Lantana camara Linn and Lantana montevidensis brig extracts from Cariri-Ceará, Brazil. J Young Pharm 2010;2:42-4.

2. De Oliveira HB, Kffuri CW, Casali VW. Ethnopharmacological study of medicinal plants used in Rosário da Limeira, Minas Gerais, Brazil. Rev Bras Farmacogn 2010;2:56-260.

3. Heywood VH. Flowering Plants of the World. London: B. T. Batsford Ltd; 1996. p. 149.

4. Kinghorn, A.D.; Balandrin, M.F.; Lin, L.J. Alkaloids of the Papilionoideae. Phytochemistry, v.21, p.2269-2275, 1982.

5. Almeida JR, Barbosa-Filho JM, Cabral AG, Agra MF, Cunha EV, Silva MS, et al. Diploflavone, a new flavonoid from Diplotropis ferruginea Benth. (Fabaceae). J Braz Chem Soc 2005;2:1454-7.

6. Cerqueira GS, Dantas JG, Mariz SR, Araujo WC, Palomaro TV, Oliveira KM, et al. Avaliação da Toxicidade aguda do extrato seco nebulizado da casca do caule de Diplotropis ferruginea Benth. Revista Brasileira de Toxicologia. 2005,v. 18 n1. sup. $88-88$.

7. Lima JT, Almeida JR, Barbosa-Filho JM, Assis TS, Silva MS, Cunha EV, et al. Spasmolytic action of diplotropin, a furanoflavan from Diplotropis ferruginea Benth., Involves calcium blockade in guinea-pig ileum. Z Naturforsch 2005:1093-100.

8. NCCLS. National Committee for Clinical Laboratory Standards. Methods for Dilution Antimicrobial Susceptibility Tests for Bacteria that Grow Aerobically- $5^{\text {th }}$ ed: Approved Standard, M7-A5. NCCLS, Wayne, PA; 2000.

9. Cleeland R, Squires E. Evaluation of new antimicrobials in vitro and in experimental animal infection. In: Lorian V, editor. Antibiotics in Laboratory Medicine. New York: Williams and Wilkins; 1991. p. 739-87.

10. Mann CM, Markham JL. A new method for determining the minimum inhibitory concentration of essential oils. J Appl Microbiol 1998;84:538-44.

11. Oliveira LI, Machado CV, Neves MW, Albuquerque CD, Silva Davi A, Agra Mde F, et al. Biological activity of Herissantia crispa (L.) Brizicky. Rev Bras Farmacogn 2009;19:249-54.

12. White A. Relation between quantitative nasal cultures and dissemination of Staphylococci. J Lab Clin Med 1970;58:273-7.

13. Thylstrup A, Fejerskov O. Características clínicas e patológicas da cárie dentária . Cariologia Clínica. $2^{\text {nd }}$ ed. cap. 6. São Paulo, Santos; 1995. p. 45-69.

14. Silva JG, Souza IA, Higino JS, Siqueira-Junior JP, Pereira JV, Pereira MS. Atividade antimicrobiana do extrato de Anacardium occidentale Linn. em amostras multiresistentes de Staphylococcus aureus. Rev Bras Farmacogn 2007;17:572-7.

15. Coutinho HD, Costa JG, Siqueira-Júnior JP, Lima EO. In vitro antistaphylococcal activity of Hyptis martiusii Benth against methicillinresistant Stapbylococcus aureus-MRSA strains. Rev Bras Farmacogn 2008;18:670-5.

How to cite this article: Cerqueira GS, Rocha N, Almeida J, de Freitas A, Lima EO, Filho J, et al. Antimicrobial activity of the extract of stem bark of Diplotropis ferruginea benth. J Young Pharmacists 2011;3:284-6.

Source of Support: CNPq and CAPES, Conflict of Interest: None declared.

Announcement

Android App

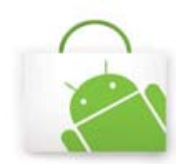

Download

Android application
A free application to browse and search the journal's content is now available for Android based mobiles and devices. The application provides "Table of Contents" of the latest issues, which are stored on the device for future offline browsing. Internet connection is required to access the back issues and search facility. The application is compatible with all the versions of Android. The application can be downloaded from https://market.android.com/details?id=comm.app.medknow. For suggestions and comments do write back to us. 